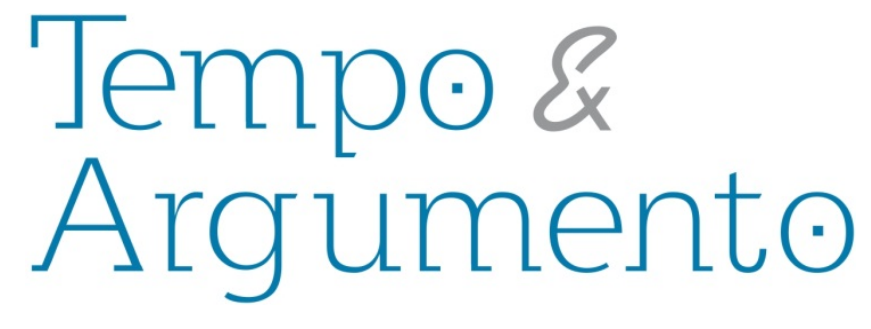

\title{
História do Partido Comunista do Brasil (PCdoB): um balanço bibliográfico
}

\section{Resumo}

O artigo apresenta um itinerário da produção histórica existente a respeito do Partido Comunista do Brasil (PCdoB). Analisa trabalhos realizados dentro e fora da universidade e aponta as principais linhas interpretativas e debates políticos que envolvem essa produção.

Palavras-chave: Partido Comunista do Brasil (PCdoB). História. Historiografia

\section{Jean Rodrigues Sales}

Doutor em História pela Universidade Estadual de Campinas (Unicamp). Professor do Programa de Pós-Graduação em História da Universidade Federal Rural do Rio de Janeiro (UFRRJ)

Nova Iguaçu, Rio de Janeiro - BRASIL jeanrodrigues5@yahoo.com.br

\section{Para citar este artigo:}

SALES, Jean Rodrigues. História do Partido Comunista do Brasil (PCdoB): um balanço bibliográfico. Revista Tempo e Argumento, Florianópolis, v. 9, n. 21, p. 290 - 311. maio/ago. 2017. 


\title{
History of the Communist Party of Brazil (PCdoB): a bibliographic review
}

\begin{abstract}
The article presents an itinerary of historical production about the Communist Party of Brazil (PCdoB). It analyzes works done inside and outside the university and points out the main interpretative lines and political debates that involve this production.
\end{abstract}

Keywords: Communist Party of Brazil (PCdoB). History. Historiography.

\section{Introdução: história dos partidos comunistas e história do tempo presente}

Escrever sobre a história do $\mathrm{PC}$ do $\mathrm{B}^{1}$ é tratar, dentro do campo historiográfico, da problemática dos partidos políticos de forma geral, e dos partidos comunistas em particular. Em primeiro lugar é preciso reconhecer que, até meados dos anos 1980, o descrédito que atingia a história política como um todo era particularmente forte no que se referia aos trabalhos sobre partidos políticos. Tais estudos, por sua vez, constituíam-se em dois grupos que, em que pese suas contribuições, apresentavam limitações evidentes diante do avanço da historiografia contemporânea. Um desses grupos corresponde às monografias nacionais ou locais preocupadas com o tecido factual da vida dos partidos. 0 outro grupo distingue-se, principalmente, pelo privilégio concedido à dimensão ideológica e pela adoção do pressuposto de que um partido se caracteriza fundamentalmente por seu projeto de sociedade (Berstein, 2003). Nas duas correntes,

\footnotetext{
1 O Partido Comunista do Brasil (PC do B) surgiu em 1962 a partir de uma cisão no Partido Comunista Brasileiro ( $\mathrm{PCB}$ ). A origem das divergências que levaram à divisão do partido está relacionada aos problemas da política nacional nos anos 1950 e 1960, bem como à crise pela qual passou o movimento comunista internacional nesse período. Para um panorama geral da trajetória do partido, ver Sales (2000).
} 

partidos, modifica-se a partir do chamado 'retorno' do político ou da nova 'nova história política'. O movimento, surgido nos anos 1980 na França, buscava uma reabilitação acadêmica dos estudos do fenômeno político. Essa nova história deixava de estudar o político em seu sentido tradicional, para pensá-lo em um nível de representações sociais, imaginário e memória coletiva, bem como práticas discursivas associadas ao poder (FALCON, 1997). E, ainda, outra abordagem foi proposta por Pierre Rosanvallon (1995, p. 16) como uma "história conceitual do político", que tem como objetivos:

1) fazer a história da maneira pela qual uma época, um país ou grupos sociais procuram construir respostas àquilo que percebem mais ou menos confusamente como um problema, e 2) fazer a história do trabalho realizado pela interação permanente entre a realidade e sua representação definindo os campos histórico-problemáticos.

Juntamente com a nova história política, também se desenvolveram na França pesquisas em torno da chamada 'história do tempo presente'. Ainda que possa contar com abordagens diversas, a maior parte dos estudos nessa área aparece relacionada à nova história política, ao uso da história oral e às discussões sobre memória e identidade. Ao refletir sobre essas relações, Marieta de Moraes Ferreira (2002) afirma que o retorno do político e a revalorização do papel do sujeito estimulam o estudo dos processos de tomada de decisão. Esse novo objeto de análise também oferece maior oportunidade ao uso dos depoimentos orais, uma vez que os arquivos escritos dificilmente deixam transparecer os meandros tortuosos dos processos decisórios. Vale lembrar que muitas decisões são tomadas através da comunicação oral, das articulações pessoais e das mais diversas formas de comunicação eletrônica e, nesse caminho, os depoimentos orais revelam-se de grande valia. ${ }^{2}$

Em termos conceituais, ganhou destaque nos estudos da nova história política o conceito de 'cultura política', que “ocupa um lugar importante para a reflexão e

\footnotetext{
${ }^{2}$ Ver ainda Motta (2012), Cardoso (2012) e Mendonça; Fontes (2012).
} 
explicação dos fenômenos políticos, permitindo detectar as continuidades no tempo de longa duração" (FERREIRA, 1992, p. 4). Esse conceito, de acordo com Serge Berstein (1998), um de seus adeptos mais conhecidos, proporciona uma dupla contribuição para a História. A primeira delas diz respeito à compreensão das motivações dos indivíduos. A segunda contribuição se refere à dimensão coletiva, pois fornece uma chave que permite compreender a coesão de grupos organizados ao redor de pressupostos comuns. Fator de comunhão dos seus membros, essa cultura comum os faria compartilhar uma mesma visão do mundo, uma leitura coletiva do passado, uma perspectiva idêntica de futuro, bem como normas, crenças e valores.

Outros autores, como Karina Kuschnir e Leandro Carneiro (1999), afirmam que o conceito de cultura política, fruto da união de diversas disciplinas como história, filosofia, antropologia, sociologia e psicologia, foi criado por Almond e Verba na década de 1960, para acrescentar aos estudos políticos uma abordagem comportamental que compreendesse a face subjetiva da política. Assim, definem ‘cultura política' como um “conjunto de atitudes, crenças e sentimentos que dão ordem e significado a um processo político, pondo em evidência as regras e pressupostos nos quais se baseia o comportamento de seus atores" (KUSCHNIR, CARNEIRO, 1999, p. 1). Ou, como indica Janaína Hilário (2006, p. 147), "um universo de percepções, sentimentos, atitudes, crenças, compromissos que definem o comportamento de um grupo, de uma instituição ou de um regime político".

É importante salientar, conforme observou Rodrigo Patto Sá Motta (2012, p. 15), que o uso do conceito de 'cultura política', ainda que contribuindo com boas perspectivas para os historiadores, deve ser aplicado de forma clara, para que não se confunda, por exemplo, com o conceito de imaginário político. Dessa forma, um partido político, com todos os seus símbolos e manifestações não implica, necessariamente, afiliação a alguma cultura política. Nesse sentido, é importante esclarecer que a utilização desse conceito neste artigo resulta do entendimento de que O PC do B insere-se dentro da cultura política comunista que predominou particularmente no século XX. Assim, apresenta, de acordo com o conceito de 'cultura política', definido por Motta (2012, p. 21), um conjunto de valores, tradições, práticas e representações políticas partilhados por um determinado 
Dentro desse panorama teórico e historiográfico, de acordo com Serge Bernstein, os historiadores iriam dar complexidade às novas pesquisas sobre partidos políticos, sendo que a principal mudança está relacionada com a perspectiva que entende um partido político como "o lugar onde se opera a mediação política". Em outras palavras, essa mediação situa-se entre o problema e o discurso, constituindo, assim, os programas partidários (BERNSTEIN, 2003, p. 60).

Às observações apontadas por Bernstein, válidas para todos os partidos políticos, devemos acrescentar elementos que dizem respeito primordialmente aos partidos comunistas. Isso porque tais partidos apresentam características que os diferenciam dos demais. Uma primeira particularidade a ser destacada diz respeito ao fato de que tanto a criação quanto as perspectivas de atuação dos grupos comunistas apresentam uma realidade complexa, relacionada à própria definição de comunismo no século XX. Sem pretender optar por uma definição fixa, vale partir da proposta de Bruno Groppo e Bernard Pudal de que o comunismo foi ao mesmo tempo um movimento político (internacional, porém estruturado sobre bases de partidos nacionais); um sistema (como o regime soviético e outros estruturados a sua imagem); uma ideologia (certa variação do marxismo), "mas também uma realidade social, cultural e uma espécie de religião (ou, em todo caso, uma doutrina de esperança). Um objeto, portanto, que apresenta múltiplas facetas" (GROPPO; PUDAL, 2000, p. 20).

São vários os autores que destacam a especificidade da estrutura e funcionamento dos partidos comunistas. Annie Kriegel (1985), por exemplo, analisa o Partido Comunista Francês (PCF) como um 'partido sociedade', no qual os laços de coesão seriam mais fortes do que nos partidos não comunistas. Gerard Vincent (1992) explica os comportamentos dos comunistas na década de 1950, na França, em relação aos crimes praticados na URSS, a partir do que ele chama de "recusa do real", que seria uma das características que formariam a "identidade comunista". Ao realizar uma análise das diversas dissidências sofridas pelo PCF no decorrer da história, Michel Dreyfus (1990) identifica uma lógica nas cisões que diriam respeito a determinado modo de 
políticas do partido, tomando cuidado para não o fazer em detrimento das contribuições dos militantes de base; levar em consideração o equilíbrio nacional de forças; não desconsiderar a tradição e a cultura nacional.

A respeito da dimensão internacional, tão presente na trajetória dos comunistas, muitas vezes acusados de serem seguidores de diretrizes externas, a interpretação dos historiadores franceses Stéphane Courtois e Marc Lazar pode ser útil para o caso brasileiro. Referindo-se ao PCF, afirmam que a história desse grupo se constitui a partir da intersecção de duas variáveis: uma, que vem das relações orgânicas com os centros revolucionários, no caso de Moscou; outra, relacionada com a inserção do partido na vida social francesa. Essas duas dimensões conviveriam na elaboração de sua política, ora em harmonia, ora em conflito com a sociedade local. Assim, escrever a história do PCF pressupõe entender "a institucionalização e articulação dessas duas dimensões, mas também as contradições que elas não deixam de provocar no aparelho partidário e junto aos militantes" (COURTOIS; LAZAR, 2000, p. 12).

Uma referência teórica importante para o estudo dos partidos comunistas diz respeito à relação existente entre memória, história e identidade partidária. A maior contribuição neste caso vem de uma autora francesa, Marie-Claire Lavabre (1994), que discute a utilização política do passado pelos comunistas no momento em que reconstituem a sua história. A autora demonstra como há uma articulação entre a história coletiva, os itinerários individuais dos componentes, a história contada pelo partido e as lembranças evocadas pelos militantes, conformando a identidade partidária. ${ }^{3}$

No mesmo caminho, Dulce Pandolfi, em seu estudo sobre a história e a memória do PCB, chama a atenção para a importância que a relação com o passado assume nos partidos comunistas, exercendo um forte papel em suas intervenções políticas. A

\footnotetext{
${ }^{3}$ Ver ainda a este respeito: Pollak (1989, 1992); Rousso (1991); Hartog; Revel (2001). No caso brasileiro, há o livro de Pandolfi (1995).
} 
referência ao passado seria um elemento fundamental na construção da identidade comunista e, ao mesmo tempo, na manutenção da coesão partidária. Segundo a autora:

Em qualquer processo de busca de identidade, a memória exerce um papel fundamental. Isso porque, além de fortalecer o sentimento de pertencimento e a continuidade temporal, uma das suas funções essenciais é manter a coesão interna e defender as fronteiras daquilo que um determinado grupo tem em comum. (PANDOLFI, 1995, p. 15)

Outra dimensão que estaria implicada nas relações entre presente e passado, memória e identidade política, seria o próprio projeto político do grupo, o qual, para se afirmar, se apoiaria fortemente na história partidária. Isso porque

todos os partidos comunistas possuem um projeto bastante definido e consistente. Em função de um objetivo maior e de longo alcance, que é a construção de uma nova sociedade, projetos menores são elaborados. Servindo a uma concepção teleológica da história, comum a todas as organizações comunistas, o presente existe em função do futuro, e é o futuro que dá forma ao passado. (PANDOLFI, 1995, p. 18)

Por fim, Michel Pollak destaca que a forma como as instituições políticas lidam com seu passado é fundamental na manutenção da coerência de seus discursos políticos. Nesse caso, a memória seria responsável pelo reconhecimento dos indivíduos na imagem que a instituição política forja de si mesma. Sem essa identificação, sem esse sentimento de pertencimento do indivíduo ao projeto político, não seria possível manter a coesão institucional necessária à atuação política:

toda organização política, por exemplo - sindicato, partido etc. - , veicula seu próprio passado e a imagem que ela forjou para si mesma. Ela não pode mudar de direção e de imagem brutalmente a não ser sob o risco de tensões difíceis de dominar, de cisões e mesmo de seu desaparecimento, se os aderentes não puderem mais se reconhecer na nova imagem, nas novas interpretações de seu passado individual e no de sua organização. $O$ que está em jogo na memória é também o sentido da identidade individual e do grupo. Temos exemplos disso por ocasião de congressos de partidos em que ocorrem reorientações que produzem rachas. (POLLAK, 1989, p. 10) 
Se está correto, como afirmam os autores acima, que os comunistas têm no passado uma fonte importante de legitimação política, não podendo mudar radicalmente de direção os seus projetos políticos sem antes reelaborar seu passado, sob risco de seus militantes não se reconhecerem e não se identificarem com o as suas próprias instituições e, assim, colocar em risco a identidade do grupo e dos indivíduos, no caso do PC do B, o problema ganhou um relevo ainda maior. Tal importância decorre da própria especificidade de sua trajetória política, ou seja, pelo fato de ter surgido como dissidência do Partido Comunista Brasileiro (PCB) e ter que demarcar as diferenças em relação a sua matriz.

Na demarcação de território político e ideológico em relação ao PCB, uma das principais ferramentas utilizadas pelo $P C$ do $B$ foi exatamente a história e a memória partidária. Com efeito, o discurso político que fundamenta a criação do partido seria estruturado a partir do respaldo no passado, tendo como exemplo mais aparente o fato de ao surgir ou, como querem seus membros, ser "reorganizado" em 1962, reivindicar para si o nome e o patrimônio simbólico do velho partido comunista fundado em 1922. Assim, foi através da utilização da história e memória partidária que o PC do B tentou convencer os seus militantes e interlocutores de que era o verdadeiro partido comunista em atuação no Brasil, aquele se mantivera dentro das autênticas tradições marxistaleninistas, enquanto o outro grupo, O PCB, teria se afastado desse caminho. Podemos dizer que essa disputa com o PCB pelo patrimônio simbólico representado pela tradição do comunismo brasileiro desde 1922 marcou toda a trajetória do PC do B, e a ela o partido dispensou muito de suas energias, o que poderemos constatar através da análise do lugar especial que a questão ocupa na narrativa histórica construída pelo PC do B.

\section{A produção historiográfica sobre o PC do B}

A discussão da historiografia existente a respeito do PC do B não pode deixar de levantar, inicialmente, um aspecto marcante a respeito dessa produção, que diz respeito a uma abordagem na qual a sua história aparece quase sempre associada à história do Partido Comunista Brasileiro (PCB). Seja por meio da comparação, seja por meio da 
oposição, a história do PC do B aparece constantemente vinculada à história do PCB. Isso se deve certamente ao fato de seu surgimento ter sido fruto de uma cisão no interior do $P C B$, sendo que neste último ficou a maior parte dos militantes. Além disso, a divisão não impediu que o partido de Luís Carlos Prestes, O PCB, se mantivesse como força hegemônica entre as esquerdas até o golpe civil-militar de 1964. Enquanto isso, o PC do B tentava compor-se organicamente e definir-se ideologicamente para se diferenciar de sua matriz. Entretanto, a despeito de seus esforços, ele teve muita dificuldade em figurar como uma alternativa viável ao PCB perante as esquerdas.

Os aspectos acima mencionados da trajetória do PC do B certamente contribuíram para que a sua história tenha sido de certa forma ofuscada pela do PCB. É sintomático, nesse sentido, que até este momento ainda não tenha sido publicada uma "história do PC do B", fruto de pesquisa acadêmica, mas apenas trabalhos que discutem aspectos parciais de sua trajetória, ao passo que há diversas obras sobre a história do PCB.

Contudo, é importante assinalar que a história do PC do B deve ser compreendida em sua especificidade, desenlaçando-a da de sua matriz. Afinal, deve-se considerar que o PC do B tem mais de 55 anos (ou 95, como querem seus membros) de existência. Tendo sobrevivido aos percalços da Ditadura Militar e dos ventos do leste europeu, é hoje o principal partido comunista em atuação no Brasil. O grupo possui, ainda, inserção junto ao movimento estudantil e sindical, além de representações em prefeituras, assembleias legislativas, senado e governo federal. Sua própria existência institucional contrasta com o enfraquecimento dos partidos comunistas no mundo após a falência, em escala global, do projeto do socialismo real que marcou século XX.

Para efeito analítico, a bibliografia existente sobre o PC do B pode ser dividida em quatro grupos: as investigações sobre sua matriz, o PCB; os trabalhos a respeito da história das esquerdas na década de 1960; livros e documentos do próprio PC do B e de militantes e, por fim, as pesquisas acadêmicas que tomaram o partido como objeto de estudo. O que se pretende neste item não é propriamente apresentar um levantamento exaustivo dessa bibliografia, mas sim apontar, a partir da indicação de algumas obras representativas, as linhas gerais de interpretação que existem nessa produção para a compreensão da história do PC do B. 
No primeiro grupo de obras importantes para o estudo a respeito do partido, estão os estudos sobre o PCB. Tais estudos aqui se encontram porque, como fora anteriormente mencionado, ambas as histórias partidárias se interpenetram, tornando a bibliografia do PCB fundamental para compreensão da trajetória do PC do B. Nesses trabalhos há uma linha interpretativa que marca fortemente as análises sobre a origem do $P C$ do $B$, que teria sido o resultado das disputas internas no PCB na segunda metade da década de 1950. Essas disputas, por sua vez, estariam ligadas ao impacto causado pelo relatório secreto apresentado por Nikita Khrushchev durante o XX Congresso do Partido Comunista da União Soviética (PCUS), no qual foram denunciados crimes praticados por Josef Stalin, causando grande impacto no movimento comunista internacional.

No Brasil, os debates internacionais teriam feito o PCB repensar a sua orientação política, o que estaria representado na formulação da "Declaração de Março de 1958" e nas teses do $V$ Congresso do partido, realizado em 1960. A cisão teria origem nas divergências de um setor do partido em relação a modificações na orientação política do PCB.

O novo partido, ainda segundo a vertente interpretativa mencionada, se singularizaria por optar pela luta armada como via privilegiada para a realização da revolução brasileira e por pregar a necessidade da liderança da classe operária na "Frente Única” revolucionária. Internacionalmente, diferenciar-se-ia pelo alinhamento ao comunismo chinês, o que colocava o Brasil no meio da disputa das duas potências comunistas, dentro do chamado cisma sino-soviético. Fazem parte desse primeiro grupo de estudos, trabalhos como os de Edgard Carone (1973), Ronald Chilcote (1982), Eliezer Pacheco (1984), Raimundo Santos (1988), José Antonio Segatto (1995), Leôncio Martins Rodrigues (1983), Moisés Vinhas (1982) e Antonio Carlos Mazzeo (1999).

É necessário frisar que não se está afirmando que todos esses estudos têm uma mesma abordagem a respeito da história do PCB. O que ressalto é sua convergência em relação à interpretação do processo que levou ao surgimento do PC do $B$, interpretação esta que se encontra cristalizada na maioria dos estudos sobre este partido. Não poderíamos, por exemplo, desconsiderar as diferenças básicas entre os estudos de Ciência Política, como o de Chilcote (1982); os de Sociologia, caso do trabalho de 
(1984); ou ainda os que mesclam história e memorialismo, como o livro de Vinhas (1982).

O segundo grupo no qual é possível encontrar referências importantes a respeito do PC do B é formado por trabalhos que se debruçaram sobre a história das esquerdas na década de 1960 e 1970, particularmente daquelas que participaram da luta armada contra o regime militar. Busca-se o entendimento da atuação do partido numa conjuntura em que, após a derrota sofrida em 1964, em grande parte atribuída à política "reformista" e "pacifista" do PCB, as esquerdas brasileiras se dividiram em um grande número de organizações que tinham pelo menos um ponto em comum: a recusa em continuar com a política até então praticada pelo PCB e, como consequência, a busca de novas formas de atuação que se traduziram na luta armada contra o regime militar.

No que diz respeito ao $P C$ do $B$, ganham destaque nessa produção as questões relacionadas ao seu projeto de guerra popular prolongada, inspirado na experiência chinesa, em um panorama no qual a maior parte dos grupos que pegou em armas contra a ditadura era influenciado pelo ideário revolucionário cubano. Nesse caso, portanto, a discussão central localiza-se em torno das motivações e dos desdobramentos do projeto de luta armada do PC do B, sendo praticamente unânime a conclusão de que essa prática, consubstanciada na guerrilha do Araguaia, foi uma grande derrota para o partido. Isso porque, além da visível e mensurável derrota militar, há a interpretação de que o PC do B, diferentemente do esperado, não conseguiu implantar o modelo da guerra popular (que pressupunha um trabalho político junto à população local), agindo, na prática, exatamente como os grupos da esquerda revolucionária de inspiração cubana, que abriam mão do trabalho político anterior à luta.

Nesse segundo grupo de estudos, estão os livros de Jacob Gorender (1998), Daniel Aarão Reis Filho (1990) e Marcelo Ridenti (1993), além da obra do jornalista Elio Gaspari (2002a; 2002b). Podemos lembrar ainda de um dos primeiros trabalhos que procurou traçar um quadro amplo da história das esquerdas na década de 1960: trata-se de uma série de artigos, em sua maioria de Marco Aurélio Garcia, publicados no jornal Em Tempo, 
O terceiro grupo de estudos é responsável por um tipo de produção que podemos chamar de "história militante". Dele fazem parte, de um lado, escritos de ex-militantes em geral críticos ao PC do B -, que representam 'ajustes de contas' com a organização. De outro lado, a produção do próprio partido, que utiliza sua história como elemento fundamental na conformação de sua identidade ideológica e na legitimação de sua prática política no presente.

Dos trabalhos de ex-militantes, o mais importante é o de Wladimir Pomar (1980), filho de Pedro Pomar, um dos fundadores do partido e membro da primeira Comissão Executiva do PC do B. Em seu livro, o autor, que também foi dirigente partidário, reconstitui o debate travado na segunda metade da década de 1970 a respeito do significado da guerrilha do Araguaia, retomando a crítica, iniciada por seu pai, que considerava esse episódio uma grande derrota militar e política na história do partido, diferentemente da interpretação oficial da direção do PC do B. O mesmo autor publicou uma biografia de seu pai, a qual pode ser vista também como uma história crítica do PC do B (POMAR, 2003).

Quanto às publicações do próprio partido sobre o seu passado, pode-se começar lembrando que o PC do B sempre dedicou grande atenção à problemática de sua história. A característica geral dos escritos é a utilização do passado para respaldar a sua atuação política no presente e reforçar a identidade ideológica da militância, conforme apontamos na primeira parte deste artigo. Os exemplos nessa área são inúmeros. Podemse citar, além dos vários livros de coletâneas de documentos publicados desde a década de $1970^{4}$, trabalhos que traçam uma trajetória do partido, como os de Haroldo Lima (1984); Marcos Cassin (1996); Haroldo Lima e Aldo Arantes (1984) e Braulio Mendes Nogueira (2001). Fazem parte ainda deste grupo as publicações de biografias e textos dos dirigentes do partido, como João Amazonas (1981, 1983); Bertolino (2002; 2004; 2013); Rangel (2002); Bercht (2002), Diógenes Arruda Câmara (2000) e Glênio Sá (1990). Ou,

\footnotetext{
${ }^{4}$ Ver publicações do próprio partido em PC do B (1974a, 1974b, 1990, 1996, 2000, 2002; s.d.).
} 
ainda, os livros sobre a guerrilha do Araguaia (SÁ, 1990; CAMPOS FILHO, 1997; PC do B, 1996, 2002), sendo que estes últimos desempenham papel importante na afirmação da identidade de sua militância. Destaca-se, finalmente, que após intenso trabalho de publicações e documentos, em 2010 o PC do B publicou um livro no qual sintetiza sua versão a respeito da trajetória partidária (RUY; BUONICORE, 2010).

Se comparada com a produção a respeito do $\mathrm{PCB}$, as pesquisas acadêmicas específicas sobre o PC do B podem ser consideradas pouco numerosas, ainda que recentemente tenha aparecido um número maior de estudos. Entre os trabalhos existentes, o tema que se destaca é o da cisão que deu origem ao partido e de sua participação na luta armada contra a ditadura militar nos anos 1970, com ênfase na discussão sobre a guerrilha do Araguaia. No caso específico da bibliografia acadêmica, fica evidente a concentração das análises a respeito dos anos 1960 e 1970. É o caso, por exemplo, da dissertação de Antonio Carlos Galdino (1994), que busca entender a estruturação do projeto de luta armada do PC do B no decorrer dos anos 1960. A pesquisa de Valter Ventura da Rocha Pomar (2000) faz um apanhado das interpretações existentes sobre a cisão que deu origem ao PC do B. Um terceiro trabalho (SALES, 2000) procura compreender o surgimento do partido e a constituição de seu primeiro projeto político, que foi elaborado no decorrer dos anos 1960 e declinou com a derrota da guerrilha do Araguaia. A dissertação de Andréa Cristina Santos (2004) é um instigante estudo sobre a atuação do partido em Salvador na década 1960, ressaltando que parte importante dos militantes atuantes no Araguaia é oriunda da capital baiana. Sobre o Araguaia, temos ainda as dissertações de Deusa Maria de Sousa (2006), Fabiana de Paula Guerra (2008), Durbens Martins Nascimento (2000), Hugo Studart (2006) e a recente tese de doutorado de Patricia Sposito Mechi (2012).

Entre os poucos trabalhos acadêmicos que analisam a história do PC do B no período posterior aos anos 1980, podemos citar basicamente as pesquisas de Jean Rodrigues Sales (2008a, 2008b) e a dissertação de José de Oliveira Santos Júnior (2009), que analisou as alianças eleitorais do partido entre 1962 e 1987. De forma geral, os temas mais relevantes neste caso são as modificações na linha política do PC do B, com o fim da ditadura e o início da Nova República. Destaque-se que foi nesse momento que o partido 
Além desses trabalhos, resta-nos citar os autores que analisaram o impacto da crise do socialismo real na trajetória do PC do B, quando o partido, obrigado pelas circunstâncias, realizou uma avaliação crítica do legado da Revolução Russa e de Josef Stalin para os comunistas brasileiros. Nesse ponto, podemos lembrar inicialmente da tese de doutorado de José Roberto Cabrera (2008), que realizou uma análise profunda da concepção de socialismo do $\mathrm{PC}$ do $\mathrm{B}$, com destaque para as consequências da crise do leste europeu, nos anos 1980, na trajetória ideológica do partido, e do artigo publicado por Marcelo Ridenti (1994-1995) e a dissertação de mestrado de Antoni Ozaí da Silva (1999). Ainda nesta temática, mesmo não tendo especificamente o PC do B como objeto de análise, tratam de sua relação com a crise do socialismo real, as pesquisas de Rodrigo Dias (2002), Izabel Cristina Gomes da Costa (2009) e Adriano Carmelo Vitorino Zão (2011).

\section{Conclusões}

De maneira geral, os trabalhos existentes sobre a história do PC do B procuram problematizar alguns núcleos temáticos de sua trajetória. Em primeiro lugar, temos a problemática da gênese, destacando o surgimento do PC do B a partir da cisão com o PCB e os debates sobre qual seria o verdadeiro partido comunista em atuação no Brasil. Um segundo tema que merece destaque na história do PC do B durante a década de 1960 é o da sua relação com o maoísmo, com destaque para discussão a respeito da suposta influência externa nas definições ideológicas e políticas do partido

Com o golpe de abril, inaugura-se uma nova fase na vida do partido, o que constitui o terceiro núcleo temático de interesse dos pesquisadores. Nesse caso, além dos problemas gerais enfrentados, comuns a todas as esquerdas, chegara a hora de o PC do $B$ testar a eficácia de sua identidade ideológica junto ao seu campo de interlocução. A grande questão seria saber se ele conseguiria aparecer como alternativa política diante da crise que se abatera sobre o PCB. 
Já no final da década de 1970, duas questões apresentam-se como mais importantes para o partido: a incorporação da AP e o debate sobre o Araguaia. A incorporação ajudou o PC do B a sustentar-se após os duros golpes sofridos ao longo da década. Ainda está para ser feito um estudo específico sobre o impacto que a entrada deste grande contingente de militantes teve nas formulações e na prática política do PC do B. Já no debate sobre o Araguaia, mais do que o passado, estava em jogo o futuro do partido. A questão era que tipo de orientação política deveria ser seguida, diante do desfecho da frustrada experiência guerrilheira.

Durante a Nova República, a história partidária é marcada por profundas mudanças, oriundas do fim do Regime Militar. Para que as transformações acontecessem, entretanto, O PC do B teve que lidar com uma série de debates tanto interna quanto publicamente. No centro das discussões, estava a elaboração de uma estratégia política que estivesse em sintonia com as aspirações democráticas da década de 1980.

A partir do final da Nova República, vemos um deslocamento à esquerda na atuação do partido, o que ficará visível em suas alianças com o PT, no campo político, e com a Central Única dos Trabalhadores (CUT), no plano sindical. Marca também a história partidária recente, a crise do socialismo real nas décadas de 1980 e 1990, que levou o partido a implementar transformações em suas formulações ideológicas e políticas. Aspecto representativo de tais modificações foi a ampliação da participação eleitoral do PC do B no período, cujo momento mais importante se deu com a chegada ao governo federal juntamente com a coligação que apoiou a candidatura de Luis Inácio Lula da Silva em 2002.

No que diz respeito às análises, pudemos perceber que, de certa forma, as pesquisas sobre o PC do B se iniciam quando se constitui a aceitação, a partir do chamado retorno da história política, de estudos sobre partidos. Além disso, possivelmente, a grande crise que se abateu sobre o PCB no início dos anos 1990 e, ao mesmo tempo, a persistência do PC do B na cena política, chegando mesmo a experimentar um relativo crescimento, pode ter levado a um maior interesse sobre a história desse partido. 


\section{Referências}

AMAZONAS, João. A socialdemocracia, instrumento do capitalismo. Princípios. São Paulo: p. 5-12, jun. 1981.

AMAZONAS, João. Socialismo. ideal da classe operária, aspiração de todos os povos. São Paulo: Anita Garibaldi, 1983.

ANDERSON, Perry. La historia de los partidos comunistas. In: SAMUEL, Raphael. (Org.). Historia popular y teoria socialista. Barcelona: Grijalbo, 1984, p. 150-165.

BERCCHT, Verônica. Coração vermelho: a vida de Elza Monnerat. São Paulo: Anita Garibaldi, 2002.

BERSTEIN, Serge. A cultura política. In: RIOUX, Jean-Pierre Rioux; SIRINELLI, JeanFrançois. Por uma história cultural. Lisboa: Espanha, 1998, p. 349-363.

BERSTEIN, Serge. Os partidos políticos. In: RÉMOND, René. Por uma história política. 2.ed. Rio de Janeiro: FGV, 2003, p. 57-98.

BERTOLINO, Osvaldo. Maurício Grabois: uma vida de combate - da batalha das ideias ao comando da guerrilha do Araguaia. São Paulo: Anita Garibaldi, 2004.

BERTOLINO, Osvaldo. Pedro Pomar: ideias e batalhas. São Paulo: Anita Garibaldi, 2013.

BERTOLINO, Osvaldo. Testamento de luta: a vida de Carlos Danielli. São Paulo: Anita Garibaldi, 2002.

CABRERA, José Roberto. O Partido Comunista do Brasil e a crise do socialismo real: rupturas e continuísmos. 2008. Tese ( Doutorado em Ciências Sociais) - Unicamp, Campinas, 2008.

CÂMARA, Diógenes Arruda . A educação revolucionária do comunista. São Paulo: Anita Garibaldi, 2000.

CAMPOS FILHO, Romualdo Pessoa. Guerrilha do Araguaia: a esquerda em armas. Goiânia: Editora da UFG, 1997.

CARDOSO, Ciro Flamarion. História e poder: uma nova história política? In: CARDOSO, Ciro Flamarion; VAINFAS, Ronaldo. (Orgs.). Novos domínios da história. Rio de Janeiro:

Elsevier, 2012, p. 37-54. 
CARONE, Edgard. O PCB (1922-1982). Rio de Janeiro: Bertrand, 1973. 3 V.

CASSIN, Marcos. Partido Comunista do Brasil (PC do B): fundação e trajetória. Piracicaba, jun. 1996. (Mimeo.)

CHILCOTE, Ronald. O Partido Comunista Brasileiro: conflito e integração (1922-1972). Rio de Janeiro: Graal, 1982.

COSTA, Izabel Cristina Gomes da. Em busca do paradigma perdido: as esquerdas brasileiras e a crise do socialismo real. 2009. Tese (Doutorado em História) -

Universidade Federal Fluminense, Niterói, 2009.

COURTOIS, Stéphane; LAZAR, Marc. Histoire du Parti Communiste Français. 2.ed. Paris: PUF, 2000.

DIAS, Rodrigo. A esquerda brasileira no contexto do fim da Guerra Fria. 2002.

Dissertação (Mestrado em História) - Universidade Federal do Rio Grande do Sul, Porto Alegre, 2002.

DREYFUS, Michel. PCF: crises et dissidences - de 1920 à nos jours. Paris: Editions Complexe, 1990.

FALCON, Francisco. História e poder. In: CARDOSO, Ciro Flamarion; VAINFAS, Ronaldo. (Orgs.). Domínios da História: ensaios de teoria e metodologia. Rio de Janeiro: Campus, 1997, p. 55-82.

FERREIRA, Marieta de Moraes. A nova "velha história”: o retorno da história política. Estudos Históricos. Rio de Janeiro: CPDOC, n.10, v.5, p. 265-271, 1992.

FERREIRA, Marieta de Moraes. História, tempo presente e história oral. Revista Topoi. Rio de Janeiro, v.3, n.5, p. 314-332, dez. 2002.

GALDINO, Antônio Carlos O Partido Comunista do Brasil e o movimento de luta armada nos Anos 60. 1994. Dissertação (Mestrado em Ciência Política) - Universidade Estadual de Campinas Campinas, , 1994.

GARCIA, Marco Aurélio. Contribuição à história da esquerda brasileira. Em Tempo. São Paulo, 1979/1980.

GASPARI, Elio. A Ditadura envergonhada. São Paulo: Companhia das Letras, 2002a.

GASPARI, Elio. A Ditadura escancarada. São Paulo: Companhia das Letras, 2002b. 
GORENDER, Jacob. Combate nas trevas. 5.ed. São Paulo: Ática, 1998.

GROPPO, Bruno; PUDAL, Bernard. Une réalité multiple et controversée. In: DREYFUS, Michel et al. Le Siècle des communismes. Paris: Les editions de L’atelier, 2000, p. 19-25.

GUERRA, Fabiana de Paula. Luta armada em foco: a guerrilha do Araguaia nas telas do cinema. 2008. Dissertação (Mestrado em História) - Universidade Federal de Uberlândia, Uberlândia, , 2008.

HARTOG, François; REVEL, Jacques. Les usages politiques du passé. Paris: Éditions de L’École des Hautes Études en Sciences Sociales, 2001.

HILÁRIO, Janaína. História política - cultura política e sociabilidade partidária: uma proposta metodológica. História Unisinos. São Leopoldo: Unisinos, v.2, n.10, p. 142-153, mai.-ago. 2006.

KRIEGEL, Annie. Les Communistes français, 1920-1970. Paris: Le Seuil, 1985.

KUSCHNIR, Karina.; CARNEIRO, Leandro Piquet. As dimensões subjetivas da política: cultura política e antropologia da política. Estudos Históricos. Rio de Janeiro: CPDOC, v.13, n.24, p. 227-250, 1999.

LAVABRE, Marie-Claire. Le fil rouge: sociologie de la mémoire communiste. Paris: Presse de La Fondation Nationale des Sciences Politiques, 1994.

LIMA, Haroldo. Itinerário de lutas do Partido Comunista do Brasil (PC do B) de 1922 a 1984. Salvador: Maria Quitéria, 1984.

MAZZEO, Antonio Carlos. Sinfonia inacabada: a política dos comunistas no Brasil. São Paulo: Boitempo, 1999.

MECHI, Patrícia Sposito. Os protagonistas do Araguaia: trajetórias, representação e práticas dos camponeses, militantes e militares na guerrilha (1972-1974). 2012. Tese (Doutorado em História) - Pontifícia Universidade Católica, São Paulo, 2012.

MENDONÇA, Sonia Regina de; FONTES, Virgínia. História e teoria política. In: CARDOSO, Ciro Flamarion; VAINFAS, Ronaldo. (Orgs.). Novos domínios da história. Rio de Janeiro: Elsevier, 2012.

MOTTA, Marcia Maria Menendes. História, memória e tempo presente. In: CARDOSO, Ciro Flamarion; VAINFAS, Ronaldo. (Orgs.). Novos domínios da história. Rio de Janeiro: Elsevier, 2012, p. 21-36. 
MOTTA, Rodrigo Patto Sá. Desafios e possibilidades na apropriação de cultura política pela historiografia. In: MOTTA, Rodrigo Patto Sá. (Org.). Culturas políticas na história: novos estudos. Belo Horizonte: Fino Traço Editora, 2012, p. 13-37.

NASCIMENTO, Durbens Martins. Guerrilha do Araguaia (1967-1975): 'paulistas' e militares na Amazônia. 2000. Dissertação (Mestrado em História) - Universidade Federal do Pará, Belém, 2000.

NOGUEIRA, Bráulio Mendes. O Partido Comunista em Campinas: uma breve história. São Paulo: Anita Garibaldi, 2001.

PACHECO, Eliezer. O Partido Comunista do Brasil (1922-1964). São Paulo: Alfa-Ômega, 1984.

PANDOLFI, Dulce. Camaradas e companheiros: memória e história do PCB. Rio de Janeiro: Relume Dumará, 1995.

PCB: vinte anos de luta política 1958-1979 (documentos). São Paulo: Livraria Ed. Ciências Humanas, 1984.

PC do B. A linha Política revolucionária do Partido Comunista do Brasil. Lisboa: Maria da Fonte, 1974a.

PC do B. Dois caminhos opostos - PC do B e PCB. São Paulo: Anita Garibaldi, s.d.

PC do B. Em defesa dos trabalhadores e do povo brasileiro: documentos do PC do Brasil de 1960 a 2000. São Paulo: Anita Garibaldi, 2000.

PC do B. Guerra popular: caminho da luta armada no Brasil. Lisboa: Maria da Fonte, 1974b.

PC do B. Guerrilha do Araguaia. São Paulo: Anita Garibaldi, 1996.

PC do B. Política e revolucionarização do partido. Lisboa: Maria da Fonte, 1974C.

PC do B. Trinta anos de conflito ideológico: marxismo e revisionismo. São Paulo: Anita Garibaldi, 1990.

PC do B. Uma epopeia pela liberdade: PC do B e Guerrilha do Araguaia 30 anos (19722002). São Paulo: Anita Garibaldi, 2002b. 
POLLAK, Michel. Memória e identidade social. Estudos Históricos. Rio de Janeiro: CPDOC, v.5, n.10, p. 200-212, 1992.

POLLAK, Michel. Memória, esquecimento e silêncio. Estudos Históricos. Rio de Janeiro: CPDOC, v.2, n.3, p. 3-15, 1989.

POMAR, Valter Ventura da Rocha. Comunistas do Brasil: interpretações sobre a cisão de 1962. Dissertação de Mestrado (História). São Paulo: Universidade de São Paulo, 2000.

POMAR, Wladimir. Araguaia, o partido e a guerrilha. São Paulo: Global, 1980.

POMAR, Wladimir. Pedro Pomar: uma vida em vermelho. São Paulo: Xamã, 2003.

RANGEL, Olivia. (Org.). Rogério Lustosa: lições da luta operária. São Paulo: Anita Garibaldi, 2002.

REIS FILHO, Daniel Aarão. A Revolução faltou ao encontro: os comunistas no Brasil. São Paulo: Brasiliense, 1990.

RIDENTI, Marcelo. O fantasma da revolução brasileira. São Paulo: Editora da Unesp, 1993.

RIDENTI, Marcelo. O impacto da crise do socialismo no Partido Comunista do Brasil, 1988-1992. Perspectivas. São Paulo, n.17-18, p. 75-94, 1994/1995.

RODRIGUES, Leôncio Martins. O PCB: os dirigentes e a organização. In: FAUSTO, Boris. (Org.). História geral da civilização brasileira: o Brasil republicano. São Paulo: Difel, 1983. v.3, p.363-443.

ROSANVALLON, Pierre. Por uma história conceitual do político. Revista Brasileira de História. São Paulo, v.15, n.30, p. 9-22, 1995.

ROUSSO, Henry. Les usages politiques du passé: histoire et mémoire. In: PESCHANSKI, Denis.; POLLAK, Michel; ROUSSO, Henry (Orgs.). Histoire Politiques et Sciences Sociales. Paris: Editions Complexe, 1991, p. 243-264.

RUY, José Carlos; BUONICORE, Augusto. (Org.). Contribuição à história do Partido Comunista do Brasil. São Paulo: Anita Garibaldi, 2010.

SÁ, Glênio. Relato de um guerrilheiro. São Paulo: Anita Garibaldi, 1990. 
SALES, Jean Rodrigues. Entre a revolução e a institucionalização: a participação eleitoral do PC do B na história recente do Brasil. Estudos Históricos. Rio de Janeiro: CPDOC, v.21, n.42, p. 241-260, jul.-dez. 2008a.

SALES, Jean Rodrigues. O Partido Comunista do Brasil e a crise do socialismo real. Revista Brasileira de História. São Paulo, v.28, n.56, p. 507-528, 2008 b.

SALES, Jean Rodrigues. Partido Comunista do Brasil - PC do B: propostas teóricas e prática política - 1962-1997. 2000. Dissertação (Mestrado em História) -

Universidade Estadual de Campinas, Campinas, 2000.

SANTOS JÚNIOR, José de Oliveira. A subalternização da classe operária na autocracia burguesa: a política de alianças eleitorais do PC do B (1962-1987). 2009. Dissertação (Mestrado em Ciências Sociais) - Universidade Estadual Paulista, Marília, 2009.

SANTOS, Andrea Cristina. Ação entre amigos: história e militância do PC do B em Salvador (1965-1973). 2004. DissertaçãoMestrado em História) - Universidade Federal da Bahia, Salvador, , 2004.

SANTOS, Raimundo. A primeira renovação pecebista: reflexos do XX Congresso do PCUS no PCB. Belo Horizonte: Oficina de Livros, 1988.

SEGATTO, José Antonio. Reforma e revolução: as vicissitudes políticas do PCB (19541964). Rio de Janeiro: Civilização Brasileira, 1995.

SOUSA, Deusa Maria de. Caminhos cruzados: trajetória e desaparecimento de quatro guerrilheiros gaúchos no Araguaia. 2006. Dissertação (Mestrado em História) - Universidade do Vale do Rio dos Sinos, São Leopoldo, 2006.

SILVA, Antonio Ozaí da. Os partidos, tendências e organizações marxistas no Brasil (19871994): permanências e descontinuidades. 1998. Dissertação (Mestrado em Ciências Sociais) - Pontifícia Universidade Católica, São Paulo,1998.

STUDART, Hugo. A lei da selva: estratégias, imaginário e discurso dos militares sobre a guerrilha do Araguaia. São Paulo: Geração Editorial, 2006.

VICENT, Gerard. Ser comunista? Uma maneira de ser. In: ÁRIES, Philippe; DUBY, Georges. (Dirs.). História da vida privada: da primeira guerra aos nossos dias. São Paulo: Companhia das Letras, 1992. v.5, p. 398-427.

VINHAS, Moisés. O partidão: a luta por um partido de massas (1922-1944). Rio de Janeiro: Graal, 1982. 
ZÃO, Adriano Carmelo Vitorino. Perspectivas da esquerda brasileira após o fim da União Soviética. Dissertação de Mestrado (História). Niterói: Universidade Federal Fluminense, 2011.

Recebido em 25/01/2017 Aprovado em 21/06/2017

Universidade do Estado de Santa Catarina - UDESC Programa de Pós-Graduação em História - PPGH Revista Tempo e Argumento Volume 09 - Número 21 - Ano 2017 tempoeargumento@gmail.com 